\title{
LENTIL ASCOCHYTA BLIGHT AND BREEDING FOR ITS RESISTANCE
}

\author{
G. YE, D.L. McNEIL and G.D. HILL \\ Plant Sciences Group, PO Box 84, Lincoln University, Canterbury, New Zealand
}

\begin{abstract}
This paper summarises existing studies of the genetics of resistance of lentils to Ascochytablight, and the genetic variation among pathogen populations with particular emphasis on the results from our programme. Breeding methods are discussed. Six pathotypes have been identified. Resistance is mainly under the control of major genes, but minor genes also play a role. Current breeding programs are based on crossing resistant cultivars with high yield cultivars and multi-location testing. Gene pyramiding, exploring slow blighting and partial resistance and the use of genes from wild relatives will be the methods used in future.

Key words: Ascochyta blight, lentil, resistance, breeding methods.
\end{abstract}

\section{INTRODUCTION}

Ascochyta blight of lentil was first identified in 1938 (Bondartzeva-Monteverde and Vassilievsky 1940) and is an important disease of cultivated lentil (Lens culinaris). It has been reported to be the major disease in many lentil production areas (Cromey et al. 1987; Erskine et al. 1994). Bondartzeva-Monteverde and Vassilievsky (1940) named Ascochyta lentis as the causal organism of Ascochyta blight of lentil. Gossen et al. (1986) suggested that Ascochyta lentis should be synonymised with A. fabae. They proposed two special forms: A. fabae f. sp. fabae for isolates from faba bean and A. fabae f. sp. lentis for isolates from lentil. This proposal has been widely accepted. However, Nasir and Bretag (1997) recently suggested that the causal pathogen of Ascochyta blight in lentil is a species that is distinct from A. fabae. Kaiser and Hellier (1993) found the sexual state and showed that $A$. fabae f. sp. lentis is heterothallic with two mating types, and that it is probably a species of Didymella.

Ascochyta blight considerably reduces seed quality and yield (Gossen and Morrall 1983; Cromey et al. 1987). Chemical, physical and cultural control is effective, but may be uneconomic (Russell et al. 1987; Morrall 1997). Disease resistance provides an additional means of control of the disease. This paper discusses genetics of resistance to Ascochyta blight, pathogenic variation and methods of breeding for resistance.

\section{GENETIC VARIATION IN HOST AND PATHOGEN \\ Genetic resources of Ascochyta blight resistance}

Genotypic differences for Ascochyta resistance are present in cultivated lentil. Disease symptoms on different accessions range from small flecks (resistant) to extensive lesions on both leaves and stems with the death of some plants (highly susceptible). Resistant lines and cultivars have been identified by extensive screening of germplasm collections and of breeding lines (Erskine and Bayaa 1993; Nasir and Bretag 1996, 1998). Resistance to blight has also been found in wild Lens species (Erskine and Bayaa 1993; Bayaa et al. 1994).

\section{Inheritance of Ascochyta blight resistance}

Several resistance genes have been proposed using segregation analysis and the genetic models suggested are summarised in Table 1. Using recombinant inbreds from two crosses between resistant (ILL 5684 and W 6 3241) and susceptible (Titore) lines, which are homozygous for the major resistance gene, Ye (2000) showed that minor genes contribute to the resistance, and may provide more durable resistance than major 
genes. However, distinguishing minor gene effects requires a scoring system better than the $1-9$ system which is frequently used (Ye 2000). The relatively small effects observed for minor genes may be due to masking effects of the major genes. Thus, minor genes may confer more resistance than has been discovered and sufficient resistance may still exist in lines containing the minor genes if major gene resistance is broken down.

Using generation-mean analysis with six basic generations of four crosses, Ye (2000) showed that genetic regulation of resistance is complicated with significant inter-loci interaction in three of four crosses. Dominant effects played an important role in all crosses. The genetic mechanisms underlying the amount of seed infection were more complicated than those for foliar resistance.

TABLE 1: Major gene(s) conferring inheritance of Ascochyta blight resistance in lentils.

\begin{tabular}{|c|c|c|c|c|}
\hline Res. parent & Sus. parent & Organ & Inheritance model & Reference \\
\hline Indian head & PI 345635 & Seed & $\begin{array}{l}\text { Two duplicated } \\
\text { recessive genes }\end{array}$ & Andrahennadi 1994 \\
\hline Indian head & Titore & Foliar & $\begin{array}{l}\text { Two additive } \\
\text { recessive genes }\end{array}$ & Ye 2000 \\
\hline $\begin{array}{l}\text { W6 } 3241 \\
(\text { L. orientalis })\end{array}$ & Invincible & Foliar & One dominant gene & Ahmad et al. 1997 \\
\hline W6 3241 & Titore & Foliar & One dominant gene & Ye 2000 \\
\hline $\begin{array}{l}\text { W6 } 3261 \\
\text { (L. orientalis) }\end{array}$ & Invincible & Foliar & One dominant gene & $\begin{array}{l}\text { Ahmad et al. } 1997 \\
\text { Parh } 1998\end{array}$ \\
\hline W6 3261 & Titore & Foliar & One dominant gene & Ahmad et al. 1997 \\
\hline W6 3261 & Titore & Foliar & $\begin{array}{l}\text { One partial dominant } \\
\text { gene with large effect } \\
\text { and one dominant gene } \\
\text { with less effect }\end{array}$ & Ye et al. 2000 \\
\hline W6 3261 & Olympic & Foliar & One dominant gene & Ahmad et al. 1997 \\
\hline $\begin{array}{l}\text { W6 } 3192 \\
\text { (L. eroides) }\end{array}$ & Titore & Foliar & $\begin{array}{l}\text { Two dominant } \\
\text { complementary genes }\end{array}$ & $\begin{array}{l}\text { Ahmad et al. } 1997 \\
\text { Ye } 2000\end{array}$ \\
\hline W6 3192 & Olympic & Foliar & $\begin{array}{l}\text { Two dominant } \\
\text { complementary genes }\end{array}$ & Ahmad et al. 1997 \\
\hline $\begin{array}{l}\text { W6 } 3222 \\
(\text { L. odemensis })\end{array}$ & Titore & Foliar & $\begin{array}{l}\text { Two dominant } \\
\text { complementary genes }\end{array}$ & Ahmad et al. 1997 \\
\hline Laird & Eston & Seed & Single recessive gene & Tay 1989 \\
\hline Laird & Titore & Foliar & Single recessive gene & Ye 2000 \\
\hline ILL5588 & Eston & Foliar & Single dominant gene & Ford et al. 1999 \\
\hline ILL5588 & Eston & Seed & Single dominant gene & $\begin{array}{l}\text { Andrahennadi } 1994 \\
\text { Vakulabharanam } \\
\text { et al. } 1997\end{array}$ \\
\hline ILL5588 & Eston & Seed & $\begin{array}{l}\text { Two dominant and } \\
\text { one recessive }\end{array}$ & Tay 1989 \\
\hline ILL5588 & Eston & Seed & $\begin{array}{l}\text { One dominant gene } \\
\text { and one recessive } \\
\text { gene }\end{array}$ & Sakr 1994 \\
\hline
\end{tabular}

\section{Genetic variation among isolates of Ascochyta blight}

There is only limited information on variation in A. fabae f. sp. Lentis (Ahmed and Morrall 1996; Ahmed et al. 1996). Nasir and Bretag (1997) identified six pathotypes out of 39 isolates based on the different reactions of the six. Most isolates were virulent to some of the cultivars, three infected all the cultivars, and five were avirulent to all the cultivars. Thus resistance is likely to be pathotype-specific. 


\section{Current breeding method}

\section{BREEDING FOR RESISTANCE}

Breeding for resistance to Ascochyta blight in lentil has been the objective of several international and national breeding programs (Erskine et al. 1994). The International Agricultural Research Institute for Drought Areas (ICARDA) has coordinated multi-location trials resulting in the registration of resistant cultivars in several countries (Russell 1994; Erskine et al. 1996). Currently, breeding for resistance uses the same method used for other traits except that several tests for resistance are added. Combined, bulk population and pedigree selection has been used successfully in both chickpea (Cicer arietinum) and lentil breeding at ICARDA (Singh 1993; Muehlbauer et al. 1995). Breeding for Asochyta blight resistance in chickpea using a modified version of this procedure has had good success (Singh 1993) and it could be used in breeding for Ascochyta blight in lentil. This procedure, as described by Singh (1993), consists of seven steps.

1. Lines with Ascochyta blight resistance to multiple pathotypes are crossed to locally adapted superior cultivars. They are then backcrossed to the adapted parent (if necessary). $\mathrm{F}_{1}$ plants are grown in optimal conditions to produce seed.

2. $\mathrm{F}_{2}$ plants are tested for resistance in field in epiphytotics with artificial inoculation. Selected resistant (rating 1 - 4) and partially resistant (5 - 6) plants are bulk harvested.

3. $F_{3}$ and $F_{4}$ bulks are advanced in disease-free conditions and selected for growth habit, branch number, flowering time, maturity and seed size. Selected $\mathrm{F}_{4}$ plants are harvested individually.

4. $\mathrm{F}_{5} / \mathrm{F}_{6}$ progenies are tested for resistance. The effects of minor genes are more obvious due to several generations of recombination.

5. Selected lines are evaluated in preliminary yield trials. High yielding lines are selected.

6. Selected lines are multi-location tested. The locations should cover the target cultivation region of the new cultivars. Tests for yield and other important traits and tests for Ascochyta blight resistance may need to be done separately. One or two superior lines with good combinations of traits can be selected.

7. On-farm test of the selected lines and cultivar registration.

The above breeding procedure relies on multi-location testing to obtain cultivars with broad resistance. This method is justified because only resistance to the prevalent pathotypes in the target region is required by producers. However, there is no guarantee that the resistant cultivars, which are identified, will be durably resistant.

\section{Multiple resistance by gene pyramiding}

\section{FUTURE BREEDING METHODS}

When there are different pathotypes and corresponding resistance genes, one method of breeding for resistance is to combine different resistance genes into a single cultivar (gene pyramiding). This allows the cultivar to be used in more diverse environments where different pathotypes are likely to be dominant. The presence of more genes implies that pathotypes have to be virulent to all of the genes before a resistant cultivar will lose its resistance (Crute 1998). Additionally, multiple resistance genes may have additive effects.

\section{Exploring slow blighting and partial resistance}

Some cultivars/lines may only be highly resistant at early growth stages. The relatively slow development of disease has been identified in rust diseases in cereals where it has been used successfully in breeding for resistance (Wilcoxson 1981). Slow blighting has been explored in breeding for Ascochyta blight resistance in chickpea resulting in the release of a cultivar with partial but durable resistance (Singh 1993). Though there are no reports on the existence of slow blighting in lentils, Ye (2000) has demonstrated differences in seedling and adult resistance.

\section{Use of wild relatives}

Genes for Ascochyta blight resistance have been identified in wild lentil species, and it is likely that more resistance sources are present in the gene pool of wild 
relatives. Therefore, the transfer of resistance genes from wild species into elite cultivars will be an important method of breeding for resistance. Viable hybrids between the cultivated and wild species are essential for the utilisation of genes from wild relatives by conventional breeding. The only wild species that can be easily intercrossed with cultivated lentil is Lens orientalis, the progenitor of the cultivated lentil (Ladizinsky 1993). However, viable hybrids have been obtained for all wild species crosses with cultivated lentil combinations by applying $\mathrm{GA}_{3}$ after pollination (Ahmad et al. 1995). This technique may lead to an efficient method to transfer useful genes, including resistance genes, from all wild species into cultivated species.In vitro culture has been used in two ways to promote the utilisation of wild relatives in lentil. One is to rescue interspecific hybrids via embryo culture (Cohen et al. 1984). The other is to enlarge the $F_{1}$ population via micropropagation of limited $F_{1}$ materials (Ye 2000) to obtain enough hybrid material for further genetic study and breeding. Recently, a system was developed for producing genetically true-to-type hybrids, and two systems were developed to produce a large amount of breeding materials for future selection (Ye 2000).

\section{Marker assisted introgression (MAI)}

Genes conferring resistance are conventionally introgressed into an elite background by repeated backcrossing. Alternatively, instead of tracking the gene itself, a marker tightly linked to the gene can be used to trace the desirable gene's segregation in the selection process (maker-assisted introgression, MAI). MAI has several advantages.

1. Tedious and troublesome tests for resistance are not required and selection can be done in normal environments.

2. Selection can be done at an earlier stage and hence generation intervals may be reduced.

3. The transfer of both dominant and recessive genes is feasible.

The results from both theoretical study and practical application have shown that MAI reduces the necessary population size and the number of generations required for developing commercial varieties (Lee 1995; Brent and Yu 1999). Using bulk segregation analysis Ford et al. (1999) identified 7 RAPD markers $(5<30 \mathrm{cM})$ linked to the resistance locus conferring Ascochyta blight resistance in ILL 5588. The closest flanking markers were approximately 6 and $14 \mathrm{cM}$ away from the resistance locus.

\section{Transgenic technology}

Transgenic technology provides plant breeders with new tools in breeding for resistance. Its main advantages are:

1. Linkage drag, which is the inheritance of undesirable genes with desirable gene, can be avoided and consequently repeated backcrossing to the elite parent is not required and considerable time is saved.

2. Resistance genes from different sources including artificial constructs can be used. This should make plant breeders less reliant on natural variation for resistance genes.

3. By inducing or enhancing plant protective mechanisms, durable and/or multiple resistance may be achieved by a single engineering effort.

Because of its great potential in improving disease resistance, extensive studies using plant species that can be easily transformed have been conducted. As a result, several promising procedures have been demonstrated and used in economically important crops (Bushnell et al. 1998; Brent and Yu 1999). In view of the results achieved in other species, several authors have tried genetic transformation in lentil (Warkentin and McHughen 1992; Chowrira et al. 1995). These studies clearly showed that transformation could be easily achieved as confirmed by GUS assay, but regeneration of transgenic plants is difficult. Electroporation of DNA into intact nodal meristems has resulted in the production of transgenic plants (Chowrira et al.1995).

\section{Correlated selection response}

Selection for resistance may result in a correlated selection response in other traits (Falconer 1989). When traits are negatively correlated, care must be taken to reduce the unfavourable response in the other traits. A recent study showed that the major gene for resistance in ILL 5588 and W6 3241 has adverse effects on seed yield/plant 
(Ye 2000). Experience in breeding for resistance in other legume species indicates the effects of selection for resistance on the content of anti-nutritional factors, digestibility and maturity need to be determined.

\section{CONCLUSION}

Considerable progress has been made in the last two decades in understanding the Ascochyta blight pathogen and the resistance of its host. However, many challenges still remain both for plant pathologists and breeders. More resistance resources need to be identified to back up breeding programs. The host-pathogen interaction system needs to be carefully characterised to efficiently utilise resistance genes. New techniques for transferring genes from wild relatives and/or other sources, for shortening the breeding process, and for increasing breeding efficiency are required.

\section{REFERENCES}

Ahmad, M., Fautrier, A.G. and McNeil, D.L., 1997. Identification and genetic characterization of different resistance sources to Ascochyta blight within the genus Lens. Euphytica 97: 311-315.

Ahmad, M., Fautrier, A.G., McNeil, D.L., Burritt, D.J. and Hill, G.D., 1995. Attempts to overcome postfertilization barrier in interspecific crosses in the genus Lens. Plant Breeding 114: 558-560.

Ahmed, S. and Morrall, R.A.A., 1996. Field reactions of lentil lines and cultivars to isolates of Ascochyta fabae f. sp. lentis. Can. J. Plant Pathol. 18: 362-369.

Ahmed, S., Morrall, R.A.A. and Sheard, J.W., 1996. Virulence of Ascochyta fabae f. sp. lentis on lentils. Can. J. Plant Pathol.18: 354-361.

Andrahennadi, C.P., 1994. Genetics and linkage of isozyme markers and resistance to seedborne Ascochyta infection in lentil. M.Sc. Thesis, Department of Crop Science and Plant Physiology, University of Saskatchewan, Canada.

Bayaa, B., Erskine, W. and Hamdi, A., 1994. Response of wild lentil to Ascochyta fabae f. sp. lentils from Syria. Genet. Crop Evol. 41: 61-65.

Bondartzeva-Monteverde, V.N. and Vassilievsky, N.I., 1940. [A contribution to the biology and morphology of some Ascochyta on Leguminosae]. Acta Inst. Bot. Acad. Sci., USSR, Series II: 354-376.

Brent, A.F. and Yu, I.C., 1999. Applications of molecular biology to plant disease and insect resistance. Adv. Agron. 66: 251-299.

Bushnell, W.R., Somers, D.A., Giroux, R.W., Szabo, L.J. and Zeyen, R.J., 1998. Genetic engineering of disease resistance in cereals. Can. J. Plant Pathol. 20: 137220.

Chowrira, G.M., Akella, V. and Lurquin, P.F., 1995. Electroporation-mediated gene transfer into intact nodal meristems in plants: generating transgenic plants without in vitro tissue culture. Mol. Biotech. 3: 17-23.

Cohen, D., Ladizinsky, G., Ziv, M. and Muehlbauer, F.J., 1984. Rescue of interspecific Lens hybrids by means of embryo culture. Plant Cell, Tiss. Org. Cult. 3: 343-347.

Cromey, M.G., Mulholland, R.I., Russell, A.C. and Jermyn, W.A., 1987. Ascochyta fabae f. sp. Lentis on lentil in New Zealand. N.Z. J. Exp. Agric. 2: 235-238

Crute, I.R., 1998. The elucidation and exploritation of gene-for-gene recognition. Plant Pathol. 47:107-113

Erskine, W. and Bayaa, B., 1993. Screening for resistance to Ascochyta blight. ICARDA Annual Report. Pp 98-99.

Erskine, W., Bayaa, B. and Saxena, M.C., 1996. Registration of ILL 5588 lentil germplasm resistant to vascular wilt and Ascochyta blight. Crop Sci. 36: 1080.

Erskine, W., Tufail, M., Russell, A., Tyagi, M.C., Rahman, M.M. and Saxena, M.C., 1994. Current and future strategies in breeding lentil for resistance to biotic and abiotic stresses. Euphytica 73: 127-135.

Facolner, D.S., 1989. Introduction to Quantitative Genetics. Longman, London.

Ford, R., Pang, E.C.K. and Taylor, P., 1999. Genetics of resistance to Ascochytablight of lentil and the identification of closely linked RAPD markers. Theor. Appl. Genet. 98: 93-98. 
Gossen, B.D. and Morrall, R.A.A., 1983. Effect of Ascochytablight on seed yield and quality of lentils. Can. J. Plant Pathol. 5: 168-173.

Gossen, B.D., Sheppard, J.W., Beauchamp, C.J. and Morrall, R.A.A., 1986.Ascochyta lentis renamed Ascochytafabae f. sp. lentis. Can. J. Plant Pathol. 8: 154-160.

Kaiser, W.J. and Hellier, B.C., 1993. Didymella sp., the teleomorph of Ascochyta fabae f. sp. Lentis on lentil straw. Phytopath. 83: 692.

Ladizinsky, G., 1993. Wild lentils. Crit. Rev. Plant Sci. 12: 169-184.

Lee, M., 1995. DNA markers and plant breeding programs. Adv. Agron. 55: 265-344.

Morrall, R.A.A., 1997. Evolution of lentil diseases over 25 years in western Canada Can. J. Plant Pathol. 19: 197-207.

Muehlbauer, F.J., Kaiser, W.J., Clement, S.L. and Summerfield, R.J., 1995. Production and breeding of lentil. Adv. Agron. 54: 283-332.

Nasir, M. and Bretag, T.W., 1996. Screening lentil for resistance to Australia isolates of Ascochyta blight. Lens Newsl. No. 23: 7-9.

Nasir, M. and Bretag, T.W., 1997. Pathogenic variability in Australian isolates of Ascochyta fabae f. sp. lentis. Aust. Plant Pathol. 26: 217-220.

Nasir, M. and Bretag, T. W., 1998. Reactions of lentil accessions from 25 different countries to Australian isolates of Ascochyta lentis. Genet. Resources Crop Evol. 45: 297-299.

Parh D. K., 1998. Interspecific mapping of the ascochyta gene(s) of lentil (Lens culinaris Medikus) using RAPD technology. MS thesis, Lincoln University, Canterbury, New Zealand.

Russell, A.C., 1994. Three new pulse cultivars for New Zealand's arable industry. Proc. Agron. Soc. N.Z. 24: 125-128.

Russell, A.C., Cromey, M.G. and Jermyn, W.A., 1987. Effects of seed treatment on seed-borne Ascochyta of lentil. Proc. Agron. Soc. N.Z. 17: 15-18.

Sakr, B., 1994. Inheritance and linkage of morphological markers and resistance to Ascochyta blight in lentil. PhD thesis, Washington State University, Pullman, Washington, USA.

Singh, K.B., 1993. Experiences, difficulties and prospects of disease resistance breeding in chickpea. Pp 241-248 In: Durability-of-disease-resistance, T. Jacobs and J.E. Parlevliet (Eds); Kluwer Academic Publishers, Dordrecht, Netherlands.

Tay, J., 1989. Inheritance of resistance to Ascochyta blight of lentil. M.Sc. Thesis, Department of Crop Science and Plant Ecology, University of Saskatchewan, Canada.

Vakulabharanam, V.R., Slinkard, A.E. and Vandenberg, A., 1997. Inheritance of resistance to Ascochyta blight in lentil and linkage between isozyme. Food Legume Research Conference III. Adelaide, Australia. p 162.

Warkentin, T.D. and McHughen, A., 1992. Agrobacterium tumefaciens-mediated beta-glucuronidase (GUS) gene expression in lentil (Lens culinaris Medik.) tissues. Plant Cell Reports 11: 274-278.

Wilcoxson, R.D., 1981. Genetics of slow rusting in cereals. Phytopath. 71: 989-993.

Ye, G., 2000. Genetic basis of Ascochyta blight in lentils. PhD thesis, Lincoln University. Canterbury, New Zealand.

Ye, G., McNeil, D.L. and Hill, G.D., 2000. Two major genes confer Ascochytablight resistance coming from Lens orientalis. N.Z. Plant Prot. 53: 109. 